\title{
Is There Any Correlation Between De Ritis Ratio and Prostate Cancer in Males Who Underwent Transrectal Prostate Biopsy?
}

\author{
Transrektal Prostat Biyopsisi Yapılan Erkeklerde De Ritis Oranı ile \\ Prostat Kanseri Arasında Herhangi Bir İlişki Var Mı?
}

\author{
(D) Yusuf Şahin, (D) Mehmet Yılmaz, (DI İbrahim Hacıbey (D Yiğit Can Filtekin, (D) Aykut Çolakerol, \\ (D) Atilla Semerciöz, (D) Ahmet Yaser Müslümanoğlu
}

University of Health Sciences Turkey, Bağcllar Training and Research Hospital, Clinic of Urology, İstanbul, Turkey

Abstract

Objective: This study aims to evaluate the diagnostic value of the De Ritis ratio (DRR) in predicting prostate cancer (PCa) and clinically significant prostate cancer (csPCa) in biopsy-naive patients with suspected $\mathrm{PCa}$.

Method: We retrospectively reviewed medical records of 282 male patients who underwent transrectal ultrasound-guided prostate needle biopsy (PNB) between January 2015 and July 2019. Demographic and clinical characteristics of the patients including digital rectal examination findings, preoperative prostate-specific antigene (PSA), aspartate aminotransferase levels, alanine aminotransferase levels, prostate volume, comorbidities and pathological findings of the PNB specimens were noted in detail for each patient. The study cohort was divided into two groups according to the histopathological results of PNB specimens (group 1: patients with benign histopathology, group 2: patients with $P C a)$. The receiver operating characteristic (ROC) curve analysis was conducted to evaluate the diagnostic performance of PSA, PSA density and DRR in predicting PCa.

Results: The median age of the participants was 64 (59-69) years. While $71.6 \%(n=202)$ of the participants were in group 1, 28.4\% $(n=80)$ of them were in group 2. The median DRR value of group 1 was 1.08 (range: 0.89-1.32), and the median DRR value of group 2 was determined as 1.19 (range: 0.95-1.56), and the median DRR value of group 2 was found to be statistically significantly higher than that of group $1(p=0.013)$. Statistically significant but a weak positive correlation was observed between $\mathrm{PCa}$ in PNB specimens and DRR $(r=0.149, p=0.012)$, while there was no statistically significant correlation between csPCa in PNB specimens and DRR $(r=0.002, p=0.983)$. The ROC curve analysis showed that the cut-off value of DRR for the presence of PCa in PNB specimens was 1.125 and

\section{Öz}

\begin{abstract}
Amaç: $\mathrm{Bu}$ çalışma, prostat kanseri şüphesi olan biyopsi olmamış hastalarda prostat kanseri ve klinik anlamlı prostat kanserini öngörmede De Ritis oranının (DRR) tanısal değerini değerlendirmeyi amaçlamaktadır.

Yöntem: Ocak 2015 ile Temmuz 2019 arasında transrektal ultrason eşliğinde prostat iğne biyopsisi (TRUS-Bx) yapılan 282 erkek hastanın tıbbi kayıtlarını retrospektif olarak inceledik. Hastaların parmakla rektal muayene bulguları, biyopsi öncesi prostat spesifik antijen (PSA), aspartat aminotransferaz ve alanin aminotransferaz düzeyleri, prostat hacmi, komorbiditeleri ve TRUS-Bx örneklerine ait patolojik bulgularını içeren demografik ve klinik özellikler her hasta için ayrıntılı olarak not edildi. Çalışma grubu, TRUS-Bx örneklerinin histopatolojik sonuçlarına göre iki gruba ayrıldı (grup 1: benign patolojili hastalar, grup 2: prostat kanseri hastaları). Prostat kanserini öngörmede PSA, PSA dansitesi ve De Ritis oranının tanısal performansını değerlendirmek için ROC eğrisi analizi yapıldı.
\end{abstract}

Bulgular: Hastaların ortanca yaşı 64 (59-69) yıl idi. Hastaların \%71,6'sı $(\mathrm{n}=202)$ grup 1'de, \%28,4'ü ( $\mathrm{n=80}$ ) grup 2'de yer aldı. Grup 1'deki DRR'nin ortanca değeri 1,08 (aralık: 0,89-1,32) ve grup 2'nin ortanca DRR değeri 1,19 (aralık: 0,95-1,56) olarak belirlendi. Grup 2 DRR medyan değeri grup 1 'den istatistiksel olarak anlamlı olarak daha yüksek bulundu $(p=0,013)$. TRUS-Bx örneklerinde prostat kanseri ile DRR arasında istatistiksel olarak anlamlı ancak zayıf bir pozitif korelasyon gözlendi $(r=0,149, p=0,012)$. Buna karşın TRUS-Bx örneklerindeki klinik anlamlı prostat kanseri ile DRR arasında istatistiksel olarak anlamlı bir korelasyon yoktu $(r=0,002$, $p=0,983)$. ROC eğrisi analizi, TRUS-Bx örneklerinde prostat kanseri varlığı için DRR'nin eşik değerinin 1,125 olduğunu gösterdi ve eğri altındaki alan 0,595 (\%95 güven aralığı $=0,518-0,672, p=0,013$ ) idi.

Address for Correspondence: Yusuf Şahin, University of Health Sciences Turkey, Bağcılar Training and Research Hospital, Clinic of Urology, İstanbul, Turkey E-mail: dryusufsahin@hotmail.com ORCID: orcid.org/0000-0001-5216-2202 Received: 12.11.2020 Accepted: 30.11 .2020

One of the authors of this article (AYM) is a member of the Editorial Board of this journal. He was completely blinded to the peer review process of the article.

Cite this article as: Şahin Y, Yılmaz M, Hacıbey I, Filtekin YC, Çolakerol A, Semerciöz A, Müslümanoğlu AY. Is There Any Correlation Between De Ritis Ratio and Prostate Cancer in Males Who Underwent Transrectal Prostate Biopsy? Bagcilar Med Bull 2021;6(1):66-72.

๑) Copyright 2021 by the Health Sciences University Turkey, Bagcilar Training and Research Hospital Bagcilar Medical Bulletin published by Galenos Publishing House. 


\section{Abstract}

the area under curve was 0.595 ( $95 \%$ confidence interval $=0.518-0.672$, $p=0.013)$ for the presence of PCa in PNB specimens.

Conclusion: This study suggests that DRR had restricted diagnostic importance in predicting PCa in biopsy-naive patients who underwent transrectal PNB.

Keywords: Alanine aminotransferase, aspartate aminotransferase, De Ritis ratio, prostate cancer

\section{Öz}

Sonuç: Bu çalışma, De Ritis oranının, transrektal prostat biyopsisi uygulanan biyopsi-naive hastalarda prostat kanserini öngörmede kısıtlı bir tanısal değeri olduğunu göstermektedir.

Anahtar kelimeler: Alanin aminotransferaz, aspartat aminotransferaz, De Ritis oranı, prostat kanseri

\section{Introduction}

Prostate cancer (PCa) is the $2^{\text {nd }}$ most common form of cancer in men worldwide with an estimated 1,276,106 new cases and 358,989 deaths per year (1). Age-standardized incidence and mortality rates are 29.3 and 7.6, respectively (per 100,000) (1). Although prostate-specific antigen (PSA) is organ specific, not PCa specific, it is still the most important biomarker in the diagnosis and follow-up process of PCa. Different serum and urine biomarkers and ratios based on PSA such as PSA density (PSAD), PSA velocity, PSA doubling time, PCa antigen 3, (-2) pro-PSA isoform, and kallikrein-like peptidase 2 were investigated for diagnostic value in PCa diagnosis and follow-up (2). In recent years, multiparametric magnetic resonance imaging-guided fusion prostate biopsy has been recommended for the evaluation of any patient who has a suspicion of PCa with or without a history of negative prior prostate needle biopsy (PNB) (2-4). However, nearly $12 \%$ of clinically significant (cs) PCa would also be missed by fusion PNB techniques (5). Therefore, new biomarkers and imaging techniques are still needed in the PCa diagnosis process.

Attention to the various serum markers like aminotransferases [aspartate aminotransferase (AST) and alanine aminotransferase (ALT)] has recently increased in the urooncologic field in terms of their predictive and prognostic value in several malignancies. De Ritis ratio (DRR), which is calculated by dividing AST to ALT, was firstly described as a diagnostic marker for viral hepatitis and then its prognostic value in several malignancies including urologic malignancies was investigated (6-8). Recently, Ha et al. (9) reported that DRR had a predictive value in detection of csPCa in patients who had a negative PNB history. Moreover, higher DRR values could accompany worsened pathological outcomes and higher biochemical recurrence ratios in patients with localized PCa (10).

The current study aims to evaluate the diagnostic value of DRR in predicting PCa and csPCa in biopsy-naive patients with suspected PCa [elevated and/or rising PSA and/or abnormal findings at digital rectal examination (DRE)] as primary outcomes. In addition, the present study aimed to compare the predictive value of DRR in addition to wellknown parameters which are associated with PCa such as PSA, PSAD and suspicious DRE findings as secondary outcomes.

\section{Materials and Methods}

\section{Study Population}

We retrospectively reviewed the medical records of 1,497 male patients who underwent transrectal ultrasound (TRUS)-guided PNB in the University of Health Sciences Turkey, Bağcllar Training and Research Hospital, Department of Urology between January 2015 and July 2019. The study was approved by the local Institutional Ethics Committee (IRB no: 2020.06.2.02.086). All steps of the study were planned and conducted following the principles of the Declaration of Helsinki. A written informed consent on admittance to hospital was obtained from all individuals, which permitted the use of respective medical information in clinical studies.

Demographic and clinical characteristics of the patients including DRE findings, preoperative PSA, AST, and ALT levels, prostate volume and PSAD, comorbidities, smoking and alcohol consumption status, and pathological findings of the PNB specimens were noted in detail for each patient. Serum AST and ALT levels, which were evaluated 1 to 4 weeks before the PNB, were obtained from the medical records of the patients. The DRR was calculated using the following formula, as previously described: the ratio of ASTto-ALT (6).

Patients who had high-grade prostatic intraepithelial neoplasia and/or atypical small acinar proliferation, who had a medical history of prostate operation, who had any other malignancy history, those using any drug potentially influence serum AST or ALT levels, and those with missing 
clinical data were excluded. Patients with chronic liver diseases (hepatitis, liver cirrhosis, hepatitis B virus or hepatitis $\mathrm{C}$ virus carriers, etc.) were also excluded. Finally, a total of 282 patients who met the inclusion criteria were included in this study. The study cohort was divided into two groups according to the histopathological results of PNB specimens (group 1: patients with benign histopathology, group 2: patients with $\mathrm{PCa}$ ).

\section{Prostate Needle Biopsy Procedure and Pathological Evaluation}

All PNB procedures were performed transrectally in a lateral decubitus position. A single dose of oral quinolone prophylaxis and rectal enema was administered to all patients in the morning of the PNB procedure. The perianal area was prepped with $10 \%$ of povidone-iodine. Periprostatic local anesthesia ( $2 \%$ lidocaine, $10 \mathrm{~mL}$ ) was applied to all patients. 12-core systematic PNB samples were taken in accordance with the European Association of Urology guidelines on PCa recommendations (2). Additional biopsies were taken if necessary (e.g. for the hypo/hyper-echoic lesions on ultrasonography).

An experienced uropathologist from our institute evaluated the PNB specimens in accordance with the 2014 International Society of Urologic Pathology criteria (11). CsPCa in PNB specimens was defined according to the Epstein criteria (12). Patients in group 2 were further subclassified as csPCa and clinically non-significant $\mathrm{PCa}$ (nsPCa) and compared statistically in terms of DRR levels and other parameters associated with PCa.

\section{Statistical Analysis}

Statistical analysis was performed using the Statistical Package for the Social Sciences (SPSS) version 25.0 software (IBM Corp., Armonk, NY, USA). The normal distribution of the quantitative data was analyzed by the KolmogorovSmirnov and Shapiro-Wilk tests. Continuous variables were expressed in median and interquartile range, while categorical variables were expressed in number and frequency. The Pearson chi-square and Fisher's Exact tests were used to compare qualitative data. Correlation coefficient and statistical significance for the relationships between DRE, PSA, PSAD, DRR, and PCa and csPCa were calculated with the Spearman's correlation analysis. A twotailed $\mathrm{p}<0.05$ was considered as statistically significant.

The receiver operating characteristic (ROC) curve analysis was conducted to evaluate the diagnostic performance of PSA, PSAD and DRR in predicting PCa. The optimal cutoff value of DRR was determined to evaluate its diagnostic scanning performance [sensitivity, specificity, positive predictive value (PPV), and negative predictive value (NPV)] for predicting PCa.

\section{Results}

The median age of the participants was 64 (59-69) years. Suspicious DRE findings were observed in $64(22.7 \%)$ patients. The median PSA and PSAD levels were 6.44 (4.4710.60) $\mathrm{ng} / \mathrm{mL}$ and $0.13(0.09-0.22) \mathrm{ng} / \mathrm{mL}^{2}$, respectively (Table 1). The median DRR level was 1.12 (0.90-1.36). PCa was detected in 80 (28.4\%) patients and 69 (24.5\%) of them were csPCa (Table 1). The demographic and clinical characteristics of the participants are summarized in Table 1.

Table 1. Demographic and clinical characteristics of the participants

\begin{tabular}{|c|c|c|c|}
\hline & & median (IQR) & n, \% \\
\hline Age (year) & & $64(59-69)$ & - \\
\hline \multirow[t]{2}{*}{ DRE } & Benign & - & $218(77.3 \%)$ \\
\hline & Suspicious & - & $64(22.7 \%)$ \\
\hline PSA (ng/mL) & & $6.44(4.47-10.60)$ & - \\
\hline $\begin{array}{l}\text { Prostate volume } \\
(\mathrm{mL})\end{array}$ & & $48(35-70)$ & - \\
\hline $\begin{array}{l}\text { PSA density (ng/ } \\
\left.\mathrm{mL}^{2}\right)\end{array}$ & & $0.13(0.09-0.22)$ & - \\
\hline AST (U/L) & & $21.25(17.60-26.00)$ & - \\
\hline ALT (U/L) & & $18.70(14.00-26.00)$ & - \\
\hline De Ritis ratio & & $1.12(0.90-1.36)$ & - \\
\hline DM (yes) & & - & $57(20.2 \%)$ \\
\hline HT (yes) & & - & $108(38.3 \%)$ \\
\hline CAD (yes) & & - & $41(14.5 \%)$ \\
\hline COPD (yes) & & - & $15(5.3 \%)$ \\
\hline CVD (yes) & & - & $10(3.5 \%)$ \\
\hline Smoking (yes) & & - & 155 (55.0\%) \\
\hline Alcohol (yes) & & - & $45(16.0 \%)$ \\
\hline \multirow[t]{5}{*}{ PI-RADS } & PI-RADS 1 & - & $29(34.9 \%)$ \\
\hline & PI-RADS 2 & - & $18(21.7 \%)$ \\
\hline & PI-RADS 3 & - & 15 (18.1\%) \\
\hline & PI-RADS 4 & - & $14(16.9 \%)$ \\
\hline & PI-RADS 5 & - & $7(8.4 \%)$ \\
\hline \multirow[t]{2}{*}{ Pathology } & Benign & - & $202(71.6 \%)$ \\
\hline & $\begin{array}{l}\text { Prostate } \\
\text { cancer }\end{array}$ & - & $80(28.4 \%)$ \\
\hline csPCa (yes) & & - & $69(24.5 \%)$ \\
\hline
\end{tabular}

IQR: Interquartile range, DRE: Digital rectal examination, PSA: Prostate-specific antigen, AST: Aspartate aminotransferase, ALT: Alanine aminotransferase, DM: Diabetes mellitus, HT: Hypertension, CAD: Coronary artery disease, COPD: Chronic obstructive pulmonary disease, CVD: Cerebrovascular disease, PI-RADS: Prostate imaging-reporting and data system, csPCa: Clinically significant prostate cancer 
The patients in group 2 were statistically significantly older than the patients in group $1(\mathrm{p}<0.001)$. The frequency of abnormal DRE findings was higher in group 2 when compared to group $1 \quad(\mathrm{p}<0.001)$. PSA levels, PSAD and DRR were statistically significantly higher in group 2 when compared to group 1 ( $\mathrm{p}<0.001$, for PSA and PSAD, $\mathrm{p}=0.013$ for DRR) (Table 2). There was no statistically significant difference between the patients with csPCa and nsPCa when they were compared according to DRR levels $(\mathrm{p}=0.983)$. There were no statistically significant differences between the groups in terms of comorbidities except hypertension frequency ( $>0.05$, for each, $p=0.045$ for hypertension) (Table 2).

In correlation analysis, it was observed that there were statistically significant correlations in varying degrees between DRE findings, PSA levels and PSA density and PCa and csPCa in PNB specimens (Table 3). Statistically significant but a weak positive correlation was observed between PCa in PNB specimens and DRR ( $\mathrm{r}=0.149$, $\mathrm{p}=0.012$ ), while there was no statistically significant correlation between csPCa in PNB specimens and DRR $(\mathrm{r}=0.002, \mathrm{p}=0.983)$ (Table 3$)$.
The ROC curve analysis showed that the cut-off value of DRR for the presence of PCa and csPCa in PNB specimens was 1.125 , for both. The area under curve (AUC) was 0.595 [95\% confidence interval $(\mathrm{CI})=0.518-0.672, \mathrm{p}=0.013$ ] for the presence of PCa in PNB specimens, and the AUC was 0.502 (95\% CI=0.318-0.686, $\mathrm{p}=0.983$ ) for the presence of csPCa in PNB specimens (Figure la, b). The DRR cut-off value (1.125) had a sensitivity of $60.0 \%$ and $60.9 \%$, and a specificity of $54.5 \%$ and $45.5 \%$ for predicting the presence of PCa and csPCa in PNB specimens, respectively. The PPV was $34.3 \%$ and NPV was $77.5 \%$ for predicting the presence of PCa in PNB specimens. The PPV was $87.5 \%$ and NPV was $15.6 \%$ for predicting the presence of csPCa in PNB specimens.

\section{Discussion}

In this retrospective study, we assessed the diagnostic value of DRR in biopsy-naive patients with suspected PCa. In addition, we also investigated the diagnostic importance of DRR in discriminating PCa and csPCa and compared it with well-known parameters that were associated with PCa such as PSA, PSAD, and DRE findings. According to

Table 2. Comparisons of the groups in terms of demographic and clinical data

\begin{tabular}{|c|c|c|c|c|c|c|}
\hline \multirow{2}{*}{\multicolumn{2}{|c|}{ Variables median (IQR) }} & \multicolumn{2}{|c|}{ Group 1 (benign) $(n=202,71.6 \%)$} & \multicolumn{3}{|c|}{ Group 2 (prostate cancer) $(n=80,28.4 \%)$} \\
\hline & & $\mathrm{n}, \%$ & median (IQR) & n, \% & $\mathbf{p}$ & \\
\hline \multicolumn{2}{|c|}{ Age (year) } & $63(58-68)$ & - & $68(63-73)$ & - & $\mathrm{a}<0.001^{*}$ \\
\hline & Suspicious & - & $28(13.9 \%)$ & - & $36(45.0 \%)$ & \\
\hline \multicolumn{2}{|c|}{ PSA (ng/mL) } & $5.71(4.18-8.26)$ & - & $10.30(6.01-32.27)$ & & $\mathrm{a}<0.001^{*}$ \\
\hline \multicolumn{2}{|c|}{ De Ritis ratio } & $1.08(0.89-1.32)$ & - & $1.19(0.95-1.56)$ & - & a $0.013^{*}$ \\
\hline \multicolumn{2}{|c|}{ DM (yes) } & - & $42(20.8 \%)$ & - & $15(18.8 \%)$ & b0.700 \\
\hline \multicolumn{2}{|c|}{ HT (yes) } & - & $70(34.7 \%)$ & - & $38(47.5 \%)$ & b $0.045^{*}$ \\
\hline \multicolumn{2}{|c|}{ CAD (yes) } & - & $26(12.9 \%)$ & - & 15 (18.8\%) & $\mathrm{b}_{0} 0.207$ \\
\hline \multicolumn{2}{|c|}{ Alcohol (yes) } & - & $32(15.8 \%)$ & - & 13 (16.3\%) & b0.933 \\
\hline
\end{tabular}

aMann-Whitney U test, bPearson chi-square test, cFisher's Exact test, ${ }^{*} \mathrm{p}<0.05$, IQR: Interquartile range, DRE: Digital rectal examination, PSA: Prostate-specific antigen, AST: Aspartate aminotransferase, ALT: Alanine aminotransferase, DM: Diabetes mellitus, HT: Hypertension, CAD: Coronary artery disease, COPD: Chronic obstructive pulmonary disease, CVD: Cerebrovascular disease

Table 3. Correlation of suspicious DRE, PSA, PSA density and DRR with histopathology

\begin{tabular}{lllllllll} 
& \multicolumn{2}{l}{ Suspicious DRE } & \multicolumn{2}{l}{ PSA $(\mathbf{n g} / \mathbf{m L})$} & \multicolumn{2}{l}{ PSA density $\left(\mathbf{n g} / \mathbf{m L}^{2}\right)$} & \multicolumn{2}{c}{ De Ritis ratio } \\
\hline & $\mathbf{r}$ & $\mathbf{p}$ & $\mathbf{r}$ & $\mathbf{p}$ & $\mathbf{r}$ & $\mathbf{p}$ & $\mathbf{p}$ & $\mathbf{r}$ \\
\hline PCa in PNB specimens & $0.335^{* *}$ & $<0.001$ & $0.352^{* *}$ & $<0.001$ & $0.439^{* *}$ & $<0.001$ & $0.149^{*}$ & 0.012 \\
csPCa in PNB specimens & $0.288^{* *}$ & 0.010 & $0.318^{* *}$ & 0.004 & $0.350^{* *}$ & 0.001 & 0.002 & 0.983 \\
\hline
\end{tabular}

DRE: Digital rectal examination, PSA: Prostate-specific antigen, DRR: De Ritis ratio, PNB: Prostate needle biopsy, csPCa: Clinically significant prostate cancer 

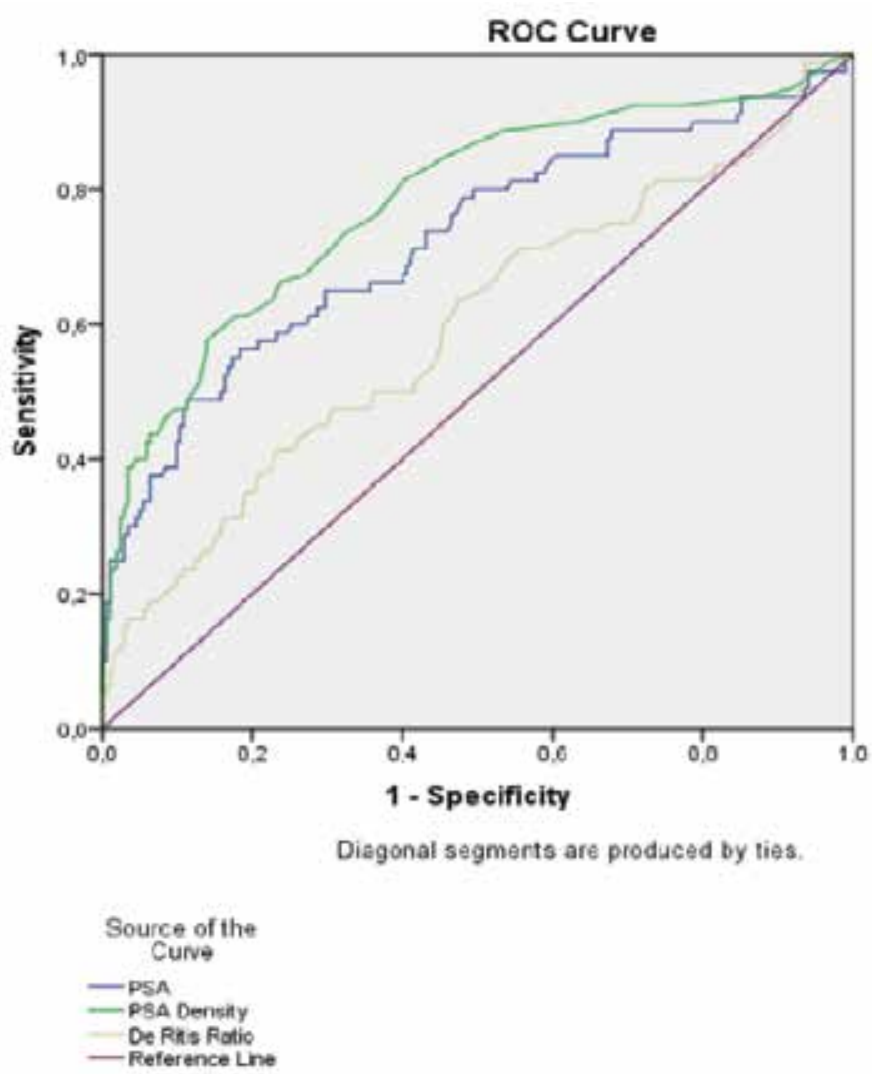

Figure 1a. ROC curve in predicting prostate cancer by De Ritis ratio

ROC: Receiver operating characteristic

our study results, higher DRR levels were associated with PCa in PNB specimens. However, no significant difference was observed between the patients with csPCa and nsPCa in terms of DRR levels. Moreover, a weak correlation was observed between PCa in PNB specimens and DRR, while no correlation was observed between csPCa in PNB specimens and DRR. In light of these outcomes, our study suggests that DRR restricted diagnostic importance in predicting PCa in biopsy-naive patients who underwent transrectal PNB. Moreover, it is insufficient in discriminating csPCa and nsPCa.

It is well-known that tumor cells need adenosine triphosphate (ATP) as energy to grow rapidly (13). Glycolysis increases in cancer cells to produce sufficient ATP (13). It has been shown that the cytosolic nicotinamide adenine dinucleotide hydride/nicotinamide adenine dinucleotide (NADH/NAD) is required for the maintenance of glycolysis. AST is one of the important components of the malate-aspartate shuttle pathway that allows NADH/NAD conversion (14). Also, while AST is commonly produced in different tissue types such as the skeletal muscle,
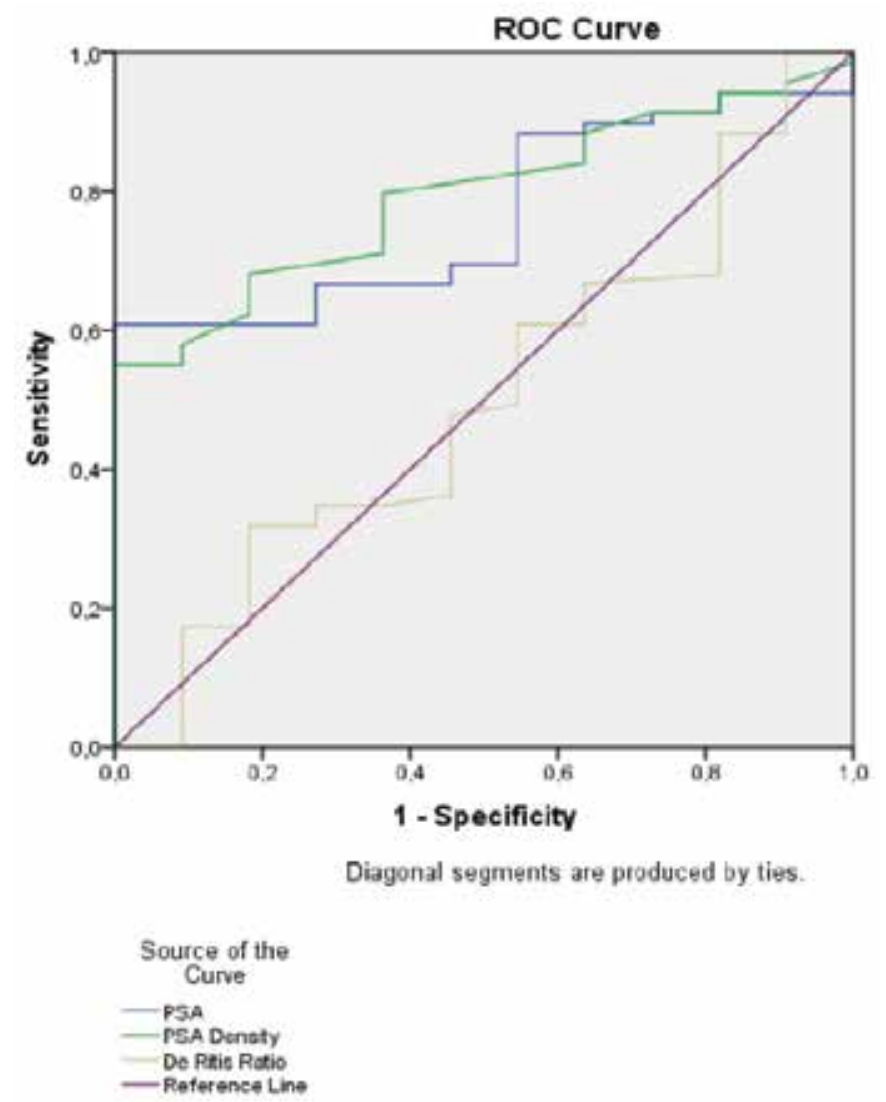

Figure $\mathbf{1 b}$. ROC curve in predicting clinically significant prostate cancer by De Ritis ratio

ROC: Receiver operating characteristic

kidney, heart, and brain, ALT is considered as more liverspecific (15). Based on these two hypotheses, many studies investigating the relationship between DRR and urogenital cancers have been published (16-20). In a recently published meta-analysis, it was emphasized that DRR was a prognostic marker in solid tumors, and it was reported that it was inversely related to overall survival (OS), recurrence free survival, and cancer specific survival (CSS) in all tumors (21). Similarly, in the systematic review and metaanalysis examining the relationship between urogenital cancers and DRR, they reported that pretreatment DRR was a significant predictor for OS, CSS, and progressionfree survival in urological cancers (22).

Although many studies have been conducted to evaluate the relationship between PCa and DRR, only few studies have focused on the relationship between pre-biopsy DRR values and PCa diagnosis (10,23-25). Zhou et al. (24) reported higher DRR values in PCa patients than in the benign prostate hyperplasia group in a recent retrospective study involving 404 patients who underwent PNB. They also reported that, according to the multivariate analysis results, the increase 
in DRR values increased the risk of PCa incidence, but they did not find a relationship between the risk groups of PCa and DRR (24). In another study, Ha et al. (9) reported that the DRR levels were higher in patients with PCa in the second biopsy compared to benign pathologies but they did not find a statistically significant difference. However, they reported that DRR was effective in detecting csPCa.

\section{Study Limitations}

Nonetheless, there are some limitations to this study. First, retrospective design of the study may have precluded the elimination of unknown confounders. Second, many patients were excluded from the study due to missing data. Finally, our sample size is low for PCa, which is known to be seen at a high rate in the society. However, the main strengths of this study are that it is one of the rare studies of the clinical use of DRR value for detecting PCa following PNB in biopsy naive males. Owing to the strength of the ROC analysis used in our study, we believe that the results of this study are valuable and clinically relevant.

\section{Conclusion}

In light of these outcomes, our study suggests that DRR has restricted diagnostic importance in predicting PCa in biopsy-naive patients undergoing transrectal PNB. Moreover, it is insufficient in discriminating csPCa and nsPCa. Although it appears to be a limited diagnostic test in our study results, we think that its joint use with risk factors related to PCa may be valuable for clinicians.

\section{Ethics}

Ethics Committee Approval: The study was approved by the Local Institutional Ethics Committee (IRB no: 2020.06.2.02.086).

Informed Consent: A written informed consent on admittance to hospital was obtained from all individuals, which permitted the use of respective medical information in clinical studies.

\section{Authorship Contributions}

Concept: Y.Ş., M.Y., A.S., A.Y.M., İ.H., Design: Y.Ş., M.Y., A.S., A.Y.M., İ.H., Data Collection or Processing: Y.F., Y.Ş., Analysis or Interpretation: A.Ç., M.Y., Writing: A.Y.M., A.S., M.Y., Y.Ş., Y.F., A.Ç., İ.H.

Conflict of Interest: No conflict of interest was declared by the authors.

Financial Disclosure: The authors declared that this study has received no financial support.

\section{References}

1. Bray F, Ferlay J, Soerjomataram I, Siegel RL, Torre LA, Jemal A. Global cancer statistics 2018: GLOBOCAN estimates of incidence and mortality worldwide for 36 cancers in 185 countries. CA Cancer J Clin 2018;68(6):394-424.

2. Mottet N, van den Bergh RCN, Briers E, Cornford P, De Santis M, Fanti S, et al. EAU - ESTRO - ESUR - SIOG Guidelines on Prostate Cancer 2020. European Association of Urology Guidelines 2020 Edition. presented at the EAU Annual Congress Amsterdam 2020. Arnhem, The Netherlands: European Association of Urology Guidelines Office; 2020.

3. Venderink W, van Luijtelaar A, Bomers JGR, van der Leest M, Hulsbergen-van de Kaa C, Barentsz JO, et al. Results of Targeted Biopsy in Men with Magnetic Resonance Imaging Lesions Classified Equivocal, Likely or Highly Likely to Be Clinically Significant Prostate Cancer. Eur Urol 2018;73(3):353-360.

4. Choi YH, Kang MY, Sung HH, Jeon HG, Chang Jeong B, Seo SI, et al. Comparison of Cancer Detection Rates Between TRUS-Guided Biopsy and MRI-Targeted Biopsy According to PSA Level in Biopsy-Naive Patients: A Propensity Score Matching Analysis. Clin Genitourin Cancer 2019;17(1):e19-e25.

5. Fourcade A, Payrard C, Tissot V, Perrouin-Verbe MA, Demany N, Serey-Effeil S, et al. The combination of targeted and systematic prostate biopsies is the best protocol for the detection of clinically significant prostate cancer. Scand J Urol 2018;52(3):174-179.

6. De Ritis F, Coltorti M, Giusti G. An enzymic test for the diagnosis of viral hepatitis: the transaminase serum activities. Clin Chim Acta 1957;2(1):70-74.

7. Ha YS, Kim SW, Chun SY, Chung JW, Choi SH, Lee JN, et al. Association between De Ritis ratio (aspartate aminotransferase/ alanine aminotransferase) and oncological outcomes in bladder cancer patients after radical cystectomy. BMC Urol 2019;19(1):10.

8. Nishikawa M, Miyake H, Fujisawa M, editors. De Ritis (aspartate transaminase/alanine transaminase) ratio as a significant predictor of recurrence-free survival in patients with upper urinary tract urothelial carcinoma following nephroureterectomy. Urologic Oncology: Seminars and Original Investigations; 2016: Elsevier. 2016;34(9):417.e9-417.e15.

9. Ha H, Chung JW, Ha YS, Choi SH, Lee JN, Kim BS, et al. Clinical significance of the De Ritis ratio for detecting prostate cancer in a repeat prostate biopsy. Investig Clin Urol 2019;60(6):447453.

10. Wang H, Fang K, Zhang J, Jiang Y, Wang G, Zhang H, et al. The significance of De Ritis (aspartate transaminase/alanine transaminase) ratio in predicting pathological outcomes and prognosis in localized prostate cancer patients. Int Urol Nephrol 2017;49(8):1391-1398.

11. Epstein JI, Egevad L, Amin MB, Delahunt B, Srigley JR, Humphrey PA, et al. The 2014 International Societ. y of Urological Pathology (ISUP) Consensus Conference on Gleason Grading of Prostatic Carcinoma: Definition of Grading Patterns and Proposal for a New Grading System. Am J Surg Pathol 2016;40(2):244-252.

12. Kryvenko ON, Carter HB, Trock BJ, Epstein JI. Biopsy criteria for determining appropriateness for active surveillance in the modern era. Urology 2014;83(4):869-874.

13. Gonzalez Menendez P, Hevia D, Mayo JC, Sainz RM. The dark side of glucose transporters in prostate cancer: Are they a new feature to characterize carcinomas? Int J Cancer 2018;142(12):2414-2424. 
14. Dorward A, Sweet S, Moorehead R, Singh G. Mitochondrial contributions to cancer cell physiology: redox balance, cell cycle, and drug resistance. J Bioenerg Biomembr 1997;29(4):385-392.

15. Botros M, Sikaris KA. The de ritis ratio: the test of time. Clin Biochem Rev 2013;34(3):117-130.

16. Yuk HD, Jeong CW, Kwak C, Kim HH, Ku JH. De Ritis Ratio (aspartate transaminase/alanine transaminase) as a significant prognostic factor in patients undergoing radical cystectomy with bladder urothelial carcinoma: a propensity score-matched study. Dis Markers 2019;2019:6702964.

17. Lee H, Choi YH, Sung HH, Han DH, Jeon HG, Jeong BC, et al. De Ritis ratio (AST/ALT) as a significant prognostic factor in patients with upper tract urothelial cancer treated with surgery. Clin Genitourin Cancer 2017;15(3):e379-e385.

18. Laukhtina E, Mostafaei H, D'Andrea D, Pradere B, Quhal F, Mori $\mathrm{K}$, et al. Association of De Ritis ratio with oncological outcomes in patients with non-muscle invasive bladder cancer (NMIBC). World J Urol, 2020; doi: 10.1007/s00345-020-03384-9 (Online ahead of print).

19. Guner E, Seker KG, Arikan Y, Huseynov C, Sam E, Ozdal OL. The utility of De Ritis Ratio in predicting prognosis in testicular cancer. Aktuelle Urol 2020;51(3):285-289.

20. Warlick C, Feia K, Tomasini J, Iwamoto C, Lindgren B, Risk M. Rate of Gleason 7 or higher prostate cancer on repeat biopsy after a diagnosis of atypical small acinar proliferation. Prostate Cancer Prostatic Dis 2015;18(3):255-259.

21. Wu J, Chen L, Wang Y, Tan W, Huang Z. Prognostic value of aspartate transaminase to alanine transaminase (De Ritis) ratio in solid tumors: a pooled analysis of 9,400 patients. Onco Targets Ther 2019;12:5201-5213.

22. Su S, Liu L, Li C, Zhang J, Li S. Prognostic role of pretreatment De Ritis ratio (aspartate transaminase/alanine transaminase ratio) in urological cancers: a systematic review and meta-analysis. Front Oncol 2020;10:1650.

23. Ha H, Chung JW, Ha YS, Choi SH, Lee JN, Kim BS, et al. Clinical significance of the De Ritis ratio for detecting prostate cancer in a repeat prostate biopsy. Investig Clin Urol 2019;60(6):447-453.

24. Zhou J, He Z, Ma S, Liu R. AST/ALT ratio as a significant predictor of the incidence risk of prostate cancer. Cancer Med 2020;9(15):56725677.

25. Miyake H, Matsushita Y, Watanabe H, Tamura K, Suzuki T, Motoyama D, et al. Significance of De Ritis (aspartate transaminase/alanine transaminase) ratio as a significant prognostic but not predictive biomarker in Japanese patients with metastatic castration-resistant prostate cancer treated with cabazitaxel. Anticancer Res 2018;38(7):4179-4185. 